\title{
И.С. Жигулина
}

Новосибирский государственный педагогический университет

\section{Поэтика «чужого» слова в лирике А. Галича}

Аннотация: В статье говорится о ролевой поэзии А. Галича, о разноплановости персонажей его произведений, носителях «чужого» слова, которым автор передает право вести повествование, рассматриваются особенности изображения центрального персонажа ролевой лирики А. Галича - советского обывателя.

The article says about the role of the poetry of an associative A. Galich, the diversity of the characters of his works, media «foreign» words, which the author conveys the right to lead story, and considers the peculiarities of the image of the Central character of the role of the lyrics an associative A. Galich - Soviet man in the street.

Ключевые слова: ролевая лирика, «чужое» слово, герой-обыватель, сатирическое изображение.

Role-playing lyrics, «alien» word, the man in the street, a satirical image.

УДК: 821.161

Контактная информация: Новосибирск, ул. Вилюйская 28. НГПУ, ИФМИП. Тел. (383) 2444041. E-mail: stepan.zhigulin@yandex.ru.

М.М. Бахтин в своей работе «Слово в романе» высказывает идею о монологической сущности лирики. Он отмечает, что поэт, в отличие от прозаика никогда не прибегает к чужому языку для освещения чужого мира. «Он должен исходить из языка как единого целого: никакое расслоение его, разноречивость и тем паче разноязычие не должны иметь сколько-нибудь существенного отражения в поэтическом произведении» [Бахтин, 1975, с. 109].

Лирика далеко не всегда способна выдержать публичное авторское исполнение. Поэзия порой на долгие периоды своего развития расходилась с этой традицией, оставляя ее в тени как второстепенную и прикладную. Такое становится возможным позже лишь в результате демократического расслоения самой общественной жизни и параллельно «обмирщения» лирики, в которой все более значительную роль, как показывает Б.О. Корман [Корман, 1967, с. 10], начинает играть «чужое слово». Иначе говоря, абсолютная монологичность как родовое отличие лирики относится к области теории, в то время как на практике при главенстве самовыражающегося единого сознания допускает ассимиляцию и выражение в нем чужих сознаний.

Качественное и количественное соотношение этих сознаний в творчестве разных поэтов различно. В зависимости от этого их поэзия в большей или меньшей степени приемлет публичное авторское исполнение, а порой и нуждается в нем. И хотя появление «чужого сознания» и, соответственно, «чужого слова» неравнозначно в творчестве разных поэтов, оно показательно в каждой фигуре органичным единством выраженных в слове самосознания, мировидения и «сценического образа» поэта.

Это «единство характера» - важнейшее условие самого существование авторской песни в 1950 - 1980 гг., так как именно оно соответствует установке на «неформальное» - личностное - выражение правды о состоянии общества, в ко- 
тором государственная монополия на мнение исключала или крайне затрудняла общественный диалог. Компенсируя этот социальный дефект, авторская песня диалогична в принципе: поэт не только обращается к залу, но и слушает зал, отвечает на его реакцию, а вслед за тем и воплощает его сознание то как «свое», то как «чужое», взаимодействующее со «своим». Это партнерство поэта и зала радость коллективного соучастия в переживании правды.

«Чужое слово» прежде всего характерно для творчества А. Галича. Присутствие в его произведениях «чужого слова» связано с ролевой лирикой. Герои многих песен А. Галича - маски, надетые говорящим. Но наряду с ролевой лирикой в творчестве А.Галича присутствует ролевая сатира, как некий стихотворный сказ, являющийся саморазоблачением говорящего - антигероя. В такого рода произведениях «чужое слово» наиболее ярко проявляется и вызывает у слушателей ответную реакцию. Общий тип героя ролевой сатиры Галича - это его современник, человек из толпы, озабоченный теми же проблемами, что и остальные.

«Текст ролевой сатиры, как и ролевой лирики, имитирует устную речь и в большинстве случаев изначально предполагает обращенность ее к собеседнику с установкой на процессуальный характер высказывания. Рассуждения говорящего, весь стиль его речи, утрированы, но именно это утрирование позволяет типизировать явление» [Жовтис, 1999, с. 254]. Такая направленность и обобщенность прекрасно распознавались слушателями.

В творчестве А. Галича ключевой оказалась тенденция к созданию разноплановой персонажной сферы, характерная для синтетической бардовской поэзии. Его песенный мир многогеройный и многоголосый, в нем выведена «панорама пестрых по своему социально-психологическому складу характеров и типов. В “ролевой” поэзии А. Галича именно этим в той или иной степени дистанцированным от авторского “я” персонажам передается право вести повествование» [Ничипоров, 2008, с. 1]. Центральный персонаж у Галича - советский обыватель. Под этой маской скрываются как простонародные герои: бывшие заключенные, рабочие, служащие, так и другие носители обывательского сознания, находящиеся на более высокой ступени социальной лестницы: директор антикварного магазина, «депутат горсовета» Клим Коломийцев.

Одним из первых произведений А. Галича, в котором создается собирательный образ обывателя, можно назвать песню «Атлант, или баллада про майора Чистова». В бытовом повествовании рассказчика проступает фантасмагоричность - герой рассказывает о своем фантастическом сне - «Мне приснилось, что я - атлант, на плечах моих шар земной!» Образ рассказчика становится неоднозначным, двуплановым, и это передается в его речи. Она имеем сказовую манеру, эмоционально двунаправлена - «И часам к десяти ноль-ноль я и вовсе тот сон забыл». Герой как бы готов к самоподавлению ради существования в тоталитарной системе, но в то же время в его речи как диссонанс прорывается ироническое недоверие, даже неосознанное для самого себя:

$$
\begin{aligned}
& \text { И открыл он мое досье, } \\
& \text { И на чистом листе, педант, } \\
& \text { Написал он, что мне во сне, } \\
& \text { Нынче снилось, что я - атлант. }
\end{aligned}
$$

Образ повествователя прорисовывается у Галича и в коллективном повествовании (через разное «чужое слово»). Например, в «Балладе про маляров, истопника и теорию относительности», повествование ведется от лица маляра, он говорит и от своего лица и от имени напарника, что расширяет повествование. Анекдотическое происшествие: истопник сообщает «ужасную историю» - «наши физики проспорили ихным физикам пари» и ответная реакция маляров, демонстрируют нам, что сознание обывателя оказывается деформированным под воздействием 
официальной пропаганды, порождает фобии к окружающему миру, вытесняет повседневное.

В речи и сознании галичевских персонажей, носителей «чужого слова» нередко существенное и поверхностное становятся неразличимы, а партийная пропаганда приобретает глобальное значение. Это порождает комический и даже гротесковый эффект. Нередки и фантастические сюжетные повороты, например, чудесное воскресение Егора Мальцева в «Балладе о сознательности», который посмел умереть вопреки партийным лозунгам.

Тональность «Баллады о том, как едва не сошел с ума директор антикварного магазина» обусловлена несовпадением настроя рассказчика - крупного советского дельца, повествующего о себе на приеме у психиатра, и объективного эффекта от всего рассказанного. В сплетении канцеляризмов с живым разговорным языком проявляется поврежденность массового сознания под воздействием неустойчивой идеологии: «Они спорят там, они ссорятся! Ну а я решай, а мне - бессонница».

Герой-обыватель существует у Галича на трех уровнях: семейно-бытовом, общественном, историческом. Рассмотрим каждый из них.

1. В песне «Красный треугольник, или товарищ Парамонова» уже само заглавие содержит пародию на атрибуты официоза. Семейная драма героя, вызванная мимолетным увлечением на стороне, обрисована в трагикомическом, откровенном сказовом повествовании от лица мужа товарища Парамоновой («вот стою я перед вами, словно голенький»). В повествование встраиваются речи и тети Паши об «аморалке» и товарища Парамоновой - партийной чиновницы, чьи речевые жесты переданы сквозными ремарками - «вся стала черная», «как увидела меня, вся стала красная». Частная жизнь становится предметом партийного обсуждения, семейные отношения переводятся на язык официозных клише: «залепили строгача с занесением», «за советскую семью образцовую». Примечательна повествовательная манера рассказчика. За видимой «идиотической» наивностью в восприятии власти скрывается язвительная усмешка над абсурдностью происходящего: «И на жалость я их брал да испытывал, и бумажку, что я псих, им зачитывал». Герой пародирует и расхожие советские формулы: «И в моральном, говорю, моем облике есть растленное влияние Запада». Изображение партийного судилища двуплановое - на грани серьезности и решительного осмеяния. В рефренах голос рассказчика приближается к авторскому голосу.

Автор, передавая право ведения повествования герою, подчас выступает у Галича как слушатель, вдумчивый свидетель рассказываемой человеческой истории, с поворотами которой он сопоставляет собственный социальный опыт, например, в «Жуткой истории, которую я услышал в привокзальном шалмане». В песне «История, проливающая свет на некоторые дипломатические тайны, или про то, как все это было на самом деле» с подзаголовком «рассказ закройщика» слово рассказчика нередко оказывается во взаимопроникновении с ироническим словом «всезнающего» автора, знающего предысторию судеб персонажей. Благодаря введению образа рассказчика создается эффект «серьезного» восприятия официальных установок, воздействующих на динамику сюжета. Языком этих установок пытается говорить герой, в изображении же Галича данный язык превращается в обезличивающую маску. И лишь в финальной звучащей на грани отчаяния реплике закройщика его голос наполняется нотами горько-ироничной авторской рефлексии: «До чего ж все, братцы, тошно и скушно».

2. В «Отрывке из репортажа о международной товарищеской встрече по футболу между сборными командами Великобритании и Советского Союза» предметом сатирического изображения становится «хамелеонская» речь комментатора, но особый интерес вызывает речь-монолог проигравшего советского спортсмена Володи Лямина. В его речи блестяще прописана пластика сниженного 
разговорного языка, косвенно передана лозунговая стилистика высказываний партийного начальства:

\author{
И пойдет теперь мурыжево: \\ Федерация, хренация. \\ Как, мол, ты не сделал рыжего? \\ Где твоя квалификация?
}

Советский обыватель высокого чиновного ранга со своей ментальностью и особенностями языковой личности представлен в цикле «Истории из жизни Клима Петровича Коломийцева, кавалера многих орденов, депутата горсовета, мастера цеха, знатного человека». Рассказы ведутся от его имени, а авторское ироничное слово звучит прежде всего в заголовках. Жанры у этих песен разные: публичные выступления героя, рассказ о загранпоездке, плач жены Клима по случаю его запоя и т.д. Это предопределило многообразие речевых ситуаций, моделей речевого поведения персонажей в разных сферах жизни. В речи Клима перемежаются элементы разговорной речи и «громогласное» ораторство.

Главным объектом сатиры у Галича становится мышление обывателя, подчиненное нелепице лозунгов, порабощающих сознание. Персонажи песен Галича беспомощны в окружающем мире, и в этом смысле глубинное значение сатиры автора заключается в художественном раскрытии гибельного влияния тоталитарной системы на мироощущение человека, на человека как на языковую личность. Галич убежден, что поэтическое слово предназначено для освобождения личности от страха зависимости от шаблонов языка, порождающих бессмысленную реальность. Противостояние индивидуальной картины мира безликому тоталитарному строю образует одну из острейших коллизий песенного творчества Галича.

3. В «Рассказе старого конармейца» сказовое повествование бывшего борца «за пролетарский гуманизм» проявляет в цепи выразительных эпизодов исторические истоки крайнего суждения личности рядового советского гражданина, которая даже на словесном уровне оказывается подчиненной шаблонам идеологии:

\author{
И так людям сказал комдив: \\ «Плохо дело, братцы-конники, \\ Позор и трепет ни за грош! \\ А гады лекари-законники \\ Твердят, что тиф разносит вошь!..» \\ $<\ldots>$ \\ И только слово было сказано, \\ Как понял я, что быть тому: \\ Поймал жида четырёхглазого- \\ И утопил его в Дону...
}

В обобщенном виде образ покорного обывателя в ряде песен предстает в авторском, сатирически заостренном слове. Это такие песни как «Баллада о чистых руках», «Песня без названия», стихотворение «Век нынешний и век минувший». Знанию об истинной исторической реальности противопоставлены здесь обывательская «премудрость жевать, и мычать, и внимать» и способность «спать спокойно». В корнях общественного протеста поэта-барда прослеживаются истоки его непримиримого конфликта с историческим временем:

Те, кто выбран, те и судьи?

Я не выбран. Но я - судья! 
Таким образом, в обширной галерее образов обывателей, которая составила большой пласт мира персонажей песен А. Галича и представлена в различных жанрово-стилевых формах, мы обнаруживаем характер трагедийного прочтения автором русской истории XX века. Рассматривая условия существования советского обывателя в семейно-бытовой, общественной, исторической жизни, изображая его речевое поведение и психологию, Галич исследовал при помощи художественных средств преломление официозных идеологических установок в сознании масс, сферу народной «мифологии» советского периода, что позволяло приблизиться к обобщениям о коренных чертах национальной ментальности, которые проступают в кризисные эпохи.

\section{Литература}

Аннинский Л.А. Счастливая несчастная Россия Галича // Аннинский Л.А. Барды. М.,1999.

Бахтин М.М. Вопросы литературы и эстетики. М., 1975.

Галич А.А. Сочинения: В 2-х т. М., 1999. Т. 1.

«Верю в торжество слова» (Неопубликованное интервью А. Галича) / Публ. А.Е. Крылов // Мир Высоцкого: Исслед. и материалы. М., 1997. Вып. 1.

Жовтис А.Л. Разоблачение советского менталитета в ролевой сатире Галича и Высоцкого // Мир Высоцкого: Исслед. и материалы. М., 1999. Вып. 3. Т. 1.

Корман Б.О. Некоторые предпосылки изучения образа автора в лирической поэзии: (Понимание лирики как системы) // Изв. Воронежск. гос. пед. ин-та. 1967. Т. 79. Вып. 1. С. 10-11.

Мальцев Ю.В. Менестрели // Мир Высоцкого: Исслед. и материалы. М., 1999. Вып. 3. Т. 1.

Ничипоров И.Б. Образ советского обывателя в песенной поэзии А. Галича. [Электронный ресурс]. Режим доступа: http:portal-slovo.ru/philology (дата обращения - 12.09.2008).

Оглоблина Н.М. Проблемы бытия в цикле стихотворений А. Галича «Истории из жизни Клима Петровича Коломийцева» // Философские аспекты культуры: материалы науч.-практич. конф. 1997 г. (секц. «Русская литература») / Под ред. Г.Р. Романовой. Комсомольск-на-Амуре, 1998.

Рассадин С.Б. Я выбираю Свободу (Александр Галич). М., 1990.

Фрумкин В. Не только слово: вслушиваясь в Галича // Заклинание Добра и Зла. М., 1991. 